\author{
住谷 隆輔, 関原 圭吾, 石黒 勇輝 \\ 長阪智, 喜納 五月
}

\begin{abstract}
要 旨
Swyer-James 症候群は呼吸器感染症後に, 胸部 X 線上一側肺もしくは肺葉の透過性立進, 肺血管陰影の減少を来す疾患で ある. 症例は 24 歳男性, 生後 3 カ月より肺炎を繰り返し, 1 歳 8 カ月で Swyer-James 症候群と診断された. 肺炎を繰り返し, 左肺は荒無肺となっていた。感染のコントロールが不良となり, 左肺全摘の方針となった。術中, 胸腔内の癒着は軽度で, 肺動脈，気管支に低形成は認めず，肺全摘を施行した．合併症なく退院，その後も感染なく経過している．Swyer-James 症候群は通常，経過観察されるが，大量の喀血，治療抵抗性の感染症など限られた適応で手術を検討する。本症例は，気管 支拡張症を伴い，感染を繰り返し，荒無肺と化したため片肺全摘を行い，良好な経過を得た. Swyer-James 症候群に対する 肺全摘は稀であるが，有効な症例も存在するため，適切な症例選択が肝要である.
\end{abstract}

索引用語：Swyer-James 症候群，気管支拡張症，片肺全摘

Swyer-James syndrome, bronchiectasis, pneumonectomy

\section{はじめに}

Swyer-James 症候群は呼吸器感染症の既往を持ち, 胸 部 X 線上一側肺もしくは肺葉の透過性克進, 及び肺血管 陰影の減少を特徵とする稀な疾患である ${ }^{1,2)}$. 原因は不明 だが, 先天的要因, 後天的要因の関与が報告されている. 検診での発見例も多く, 予後良好な疾患であり, 経過観 察とされることが多い3). 今回, 感染の反復により荒無肺 と化し，外科的切除を施行した 1 例を経験した.

\section{症例}

症 例 : 24 歳, 男性.

主 訴: 咳嗽.

既往歴：気管支喘息, 双極性障害, 虫垂炎.

喫煙歴：なし。

現病歴：生後 3 カ月より肺炎を繰り返し, 前医で左肺 低形成, 気管支拡張症を指摘された. 1 歳 8 力月の時に左

国立国際医療研究センター呼吸器外科

原稿受付 2018年10月 1 日

原稿採択２018年10月23日
肺の透過性元進，肺血管陰影の減少を認め，気管支造影 検査で気管支閉鎖の所見はなく, Swyer-James 症候群と 診断された (Fig. 1A-B)。その後も感染を繰り返し, 6 歳より内服治療, 在宅酸素療法施行されていた. 18 歳ま でに左肺は荒囬肺となっており，呼吸困難による救急搬 送や入院を繰り返していた. 24 歳で感染による入院の頻 度が 1 カ月に 1 回程度に増悪したことより手術目的に呼 吸器外科へ紹介された。

入院時現症：体温 36.9 度, 心拍 99 回/分, 血圧 126/71 $\mathrm{mmHg}, \mathrm{SpO}_{2} 97 \%$ (室内気).

血液検查所見：白血球 $4840 / \mu \mathrm{l}, \mathrm{Hb} 16.0 \mathrm{~g} / \mathrm{dl}$, 血小板 25.3 万/ $\mu \mathrm{l}$, AST $35 \mathrm{U} / \mathrm{l}$, ALT $70 \mathrm{U} / \mathrm{l}$, BUN $17.5 \mathrm{mg} / \mathrm{dl}$, Cr $0.68 \mathrm{mg} / \mathrm{dl}, \quad$ CRP $0.1 \mathrm{mg} / \mathrm{dl}$.

呼吸機能検査: FVC 3.04 L/58.9\%, FEV1.0 1.86 L/ $61.2 \%$.

血液ガス分析： pH 7.40, $\mathrm{PaO}_{2} 83.9$ torr, $\mathrm{PaCO}_{2} 42.0$ torr, $\mathrm{HCO}_{3} 25.7 \mathrm{mmol} / \mathrm{l}$.

胸部 $\mathrm{X}$ 線検查 : 気管は左方に偏位し, 左肺の上肺野は 下肺野と比較し，やや透過性が保たれているが，びまん 性に浸潤影を呈している（Fig. 2).

胸部造影 CT : 左肺は気管支拡張が集簇し, 多数の囊 


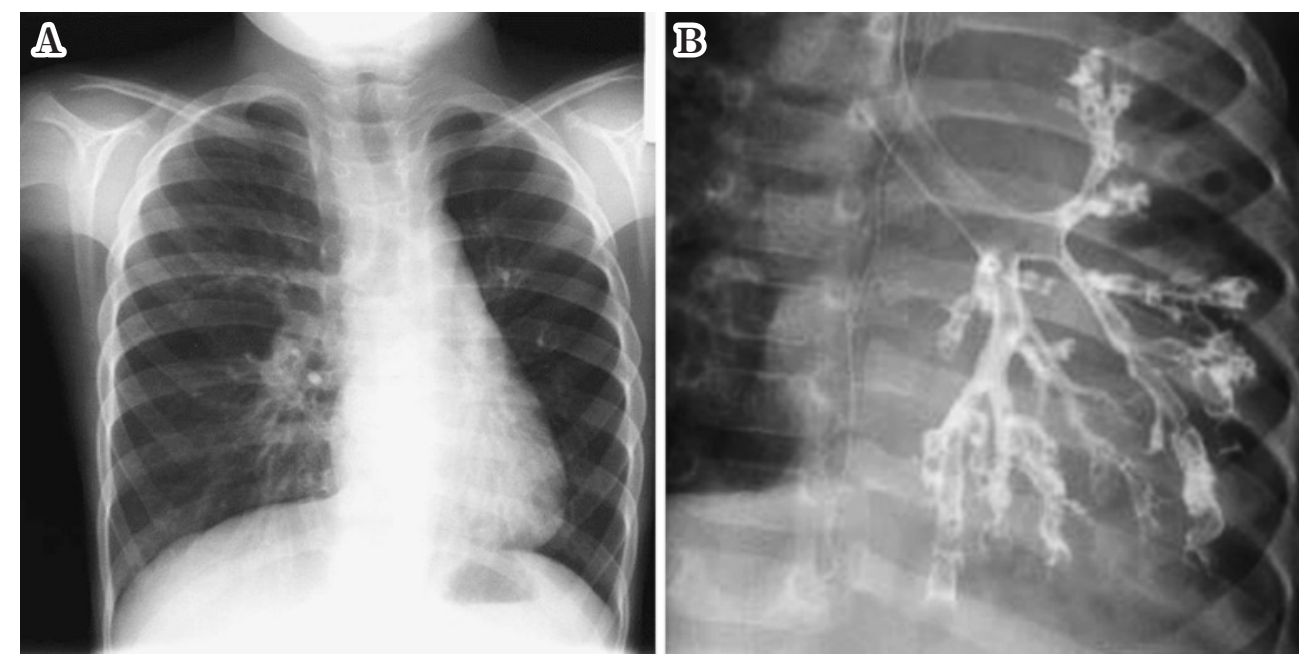

Fig. 1 A: Radiograph of the chest revealed a hyperlucent left lung and decreased pulmonary vascularity.

B: Bronchus was well-described to periphery without anomaly.

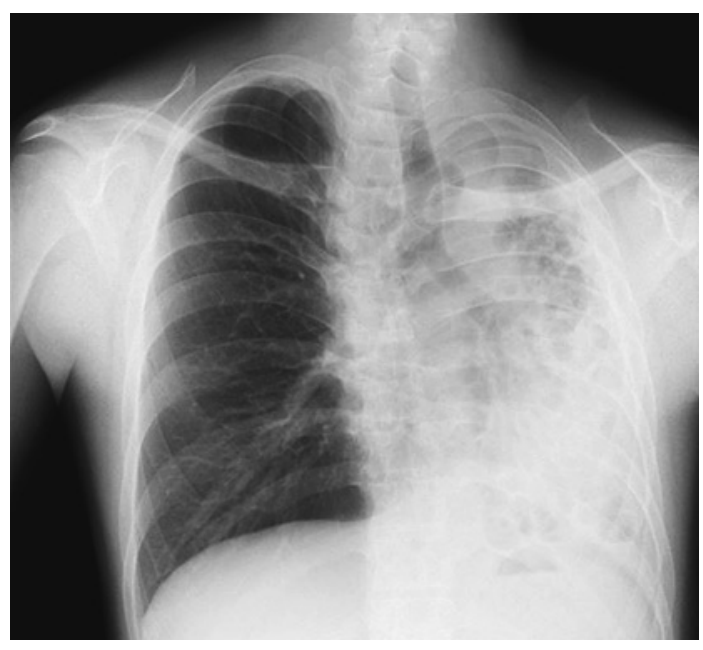

Fig. 2 Radiograph revealed that the main trachea had shifted to the left side and left lung had a diffuse infiltrative shadow.

胞に置換されている. 左肺に高度の容積減少がみられ, 縦隔が左方に偏位している (Fig. 3A).

肺血流シンチグラフィ $\left.{ }^{99 \mathrm{~m}} \mathrm{Tc}-\mathrm{MAA}\right)$ ：左肺血流 $2.5 \%$, 右肺血流 97.5\% (Fig. 3B).

手術所見: 手術は後側方切開, 第 6 肋骨床開胸アプ ローチで行った. 肺尖に索状の癒着, 背側に大動脈に沿っ た索状癒着, 腹側に軽度の索状癒着を認めるのみであっ た. 上葉を尾側に脱転し, 頭側より肺動脈本幹を同定, 切離した. 左主気管支を同定し, 肺勒帯を切り上げ，尾
側より下肺静脈を同定後, 左主気管支, 下肺静脈を切離 した. 上肺静脈は圧排され扁平であったが, 左肺動脈, 気管支に低形成は認めなかった(Fig. 4). 出血量 $83 \mathrm{ml}$, 手術時間 3 時間 14 分.

術後経過：2病日で胸腔ドレーンを抜去し，12病日で 自宅退院となった. その後も感染の再発なく経過してい る.

病理所見 : 気管支周囲, 胸膜直下の中小動脈に内膜肥 厚, 中膜平滑筋増生が見られた。 内宮が完全に閉塞した 像も散見された。気管支は拡張が目立つが, 構造異型や 内腔閉塞像は見られなかった。 肺胞構造の破壊や線維化 が目立ったが, 一部肺胞構造も残存していた。

\section{考察}

Swyer-James 症候群は胸部 X 線での,一側肺または肺 葉の透過性元進及び肺血管院影の現象を特徴とする疾患 として, 1953 年に Swyer らにより報告された ${ }^{1}$. 原因は 繰り返す気道感染による後天的病因説, 肺動脈低形成等 の先天的病因説が提唱されている ${ }^{4 \cdot 6)}$.

小児例で繰り返す気道感染の検查における胸部 X 線 で診断される例が多いことや, 幼少期の気道感染を伴う 成人発見例が多いこと，アデノウイルスとの関連性が報 告されていることからも, 後天病因説が有力である. し かし, Swyer-James 症候群と診断する上で, 多くは幼少 期の繰り返す気道感染の既往が重要視されているが, 発 

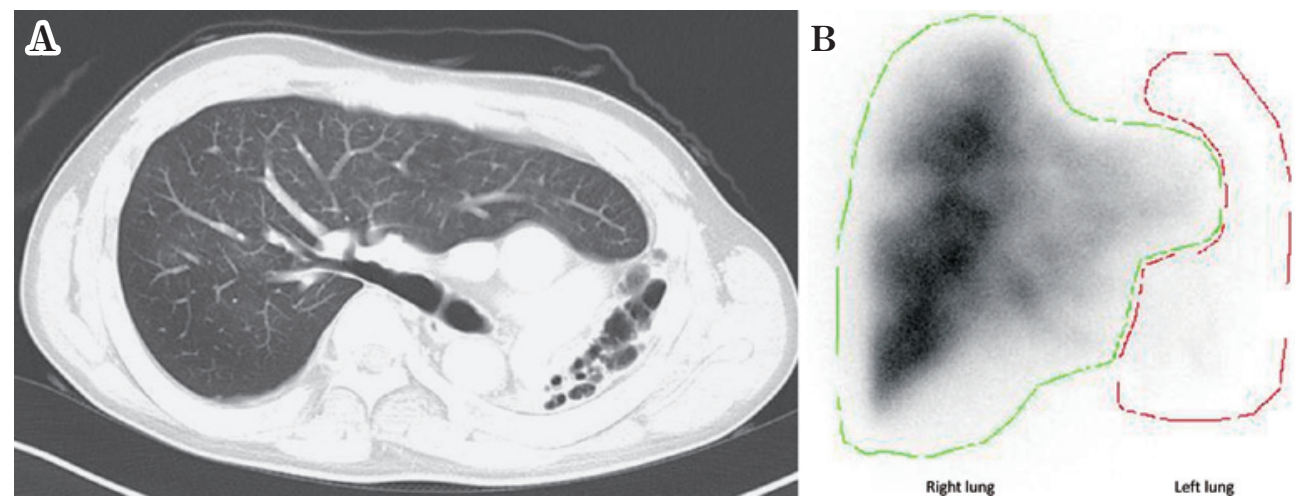

Fig. 3 A: Chest CT revealed that the left lung had been replaced by numerous cysts, the volume of the left lung had decreased, and the mediastinum had shifted to the left side. CT: computed tomography

B: Vascular flow to the left lung had markedly decreased (left lung $2.5 \%$ vs. right lung $97.5 \%)$.

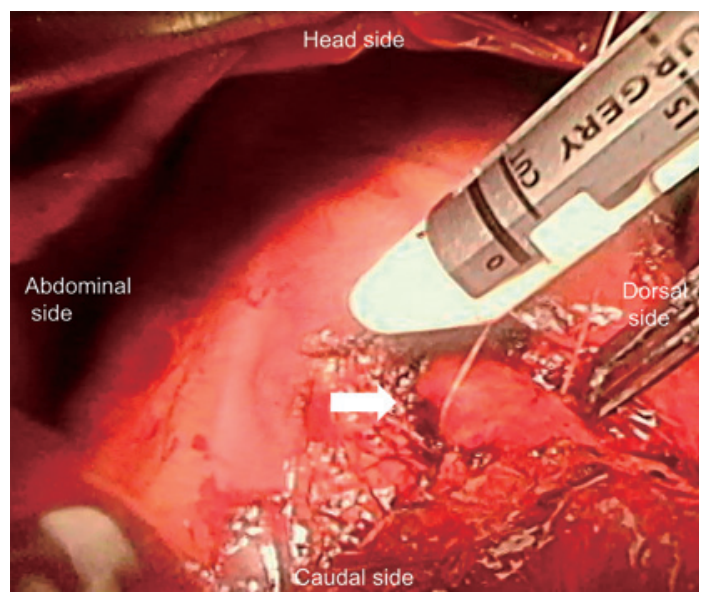

Fig. 4 During the operation, we identified no congenital anomaly involving the pulmonary artery or bronchus (Arrowhead: Pulmonary artery).

生分布が男性, 左肺に多い特徴や明らかな気道感染のな い症例も報告されていることから，先天的要因の関与が 考えられている ${ }^{3 \cdot 7}$. Swyer-James 症候群は画像での診断 が主であり,誘因の明らかな疾患を除外して診断される。 本症例は，気管支拡張症を背景とし，感染を繰り返して いたこと, 幼少期の胸部 X 線, CT 所見, 気管支造影検查 により Swyer-James 症候群と診断された.

Swyer-James 症候群は検診で発見される例も多く, 予 後良好な疾患である。無症状であれば経過観察されるこ とが多い. 呼吸器感染症の合併例も, 内科的治療が優先 される。しかし，大量の喀血がある場合や，内科治療抵
抗性の感染症，患側肺の切除により肺機能の改善が見込 まれる場合には外科的治療が検討されるが，報告は少な い.また気管支拡張の有無が内科治療抵抗性や感染の頻 度に大きく影響するとの報告もある7-11)。本症例では，気 管支拡張症を伴う, 繰り返す感染により, 患側は荒唖肺 と化し，頻回に感染，入院を繰り返していたために肺全 摘の適応とした. 吉田らは Swyer-James 症候群の肺癌合 併例に対して，患側肺の容積が $40 \%$ 未満であり，肺動脈 造影で著明な血流低下，換気血流シンチで血流低下を認 めたことから患側肺機能が著しく低下していると判断し 左肺全摘出術を施行したと報告した ${ }^{12}$. 本症例でも, 術前 の換気血流シンチでは患側肺血流は $2.5 \%$ まで低下し, 機 能は廃絶していたため, 肺全摘の方針となった。手術で は，結果的に癒着はわずかであったが，高度な癒着も予 想されたため第 6 肋骨床開胸とし, 胸膜外での剥離, 心 囊内での血管処理も想定して手術に臨んだ。術後合併症 なく退院し, 感染の再燃なく良好な経過をたどっている.

Swyer-James 症候群に対する手術は限定的であり, 病 理所見の蓄積はそしい，気腫性変化，気管支壁肥厚，気 管支拡張，細気管支閉塞，肺動脈壁肥厚が報告されてい るが，症例によるばらつきが多い9-12)。本性例では気管支 拡張像と肺動脈の壁肥厚の久が観察され，気腫性変化や 細気管支閉塞は見られなかった，先天的な異常を示唆す る病理学的所見はなく，気管支拡張像，肺動脈の壁肥厚 など, 繰り返す気道感染として矛盾しない所見であった。 Sweyr-James 症候群は単一の疾患ではないため, 病態解 明にも今後の病理学的所見の蓄積は重要である. 


\section{結語}

気管支拡張症を伴い, 感染を繰り返した Swyer-James 症候群に対して片肺全摘を行った. Swyer-James 症候群 に対する肺全摘は稀であるが, 有効な症例も存在するた め, 適切な症例選択が肝要である.

\section{利益相 反}

本論文について申告する利益相反はない.

\section{文献}

1. Swyer PR, James GC. A case of unilateral pulmonary emphysema. Thorax 1953; 8: 133-6.

2. Macleod WM. Abnormal Transradiancy of one lung. Thorax 1954; 9: 147-53.

3. 大石修司, 人見秀昭, 酒井正雄, 小林英夫, 永田直一. Swyer-James 症候群 5 例の臨床的検討. 日胸疾患会誌 1995; 33: 1401-7.

4. Sulaiman A, Cavaille A, Vaunois B, Tiffet O. SwyerJames-MacLeod syndrome; repeated chest drainages in a patient misdiagnosed with pneumothorax. Interact Cardiovasc Thorac Surg 2009; 8: 482-4.
5. Reid L, Simon G. Unilateral lung transradiancy. Thorax 1962; 17: 230-9.

6. Kent DC. Physiologic aspects of idiopathic unilateral hyperlucent lung, with a review of the literature. Am Rev Respir Dis 1964; 90: 202-12.

7. 中村武博, 吉井千春, 矢寺和博, 城戸優光. Swyer-James 症候群について. 呼吸 2007; 26: 1035-8.

8. Lucaya J, Gartner S, García-Peña P, Cobos N, Roca I, Linan S. Spectrum of Manifestations of Swyer-JamesMacLeod Syndrome. J Comput Assist Tomogr 1998; 22: 592-7.

9. 廣岡さゆり, 小嶋圭介, 岡本真一郎, 入來豊久, 増永愛子, 大場康臣, 他. 繰り返す肺炎を合併し外科的治療を要した Swyer-James 症候群の 1 例. 日呼吸誌 2014; 3: 708-12.

10. 中村昌樹, 諏訪大八郎, 東 幸宏, 馬場 聡. Swyer-James 症候群の 1 手術例. 日臨外会誌 2002; 63: 1892-6.

11. 森田克哉, 清水淳三, 亀水 忠, 渡辺洋宇, 野々村昭孝, 北啓一朗. 著明な気道狭窄を呈したSwyer-James 症候群 に対する 1 手術例. 日胸外会誌 1994; 42: 1949-52.

12. 吉田和浩, 小場弘之, 五十嵐知文, 中川 晃, 西山 薰, 原田尚雄, 他. Swyer-James 症候群の 1 例一伸展固定肺 による形態学的検討一. 日胸疾患会誌 1994; 32: 856-60. 


\title{
Pneumonectomy for Swyer-James syndrome to control refractory infection
}

\author{
Ryusuke Sumiya, Keigo Sekihara, Yuki Ishiguro \\ Satoshi Nagasaka, Satsuki Kina \\ Department of Thoracic Surgery, National Center for Global Health and Medicine
}

Swyer-James syndrome is a rare disease known as unilateral hyperlucent lung syndrome. It is caused by decreased pulmonary vascularity and hyperinflation.

Most patients have no symptoms. Although patients are usually followed up without medical care, few cases have surgical indications. Case: A 24-year-old male patient who has been followed up for Swyer-James syndrome since 1 year and 8 months old. He underwent pneumonectomy for infection control. During the operation, we identified no congenital anomaly involving the pulmonary artery or bronchus. There was no adhesion between the left lung and visceral pleura. He was discharged 12 days after the operation and the post-operative course has been uneventful. Most patients are followed up with no medical care. However, few cases, such as patients with marked hemoptysis or infection that show resistance to medical treatment, are recommended for surgery. In this case, the patient had bronchiectasis and repeated infection that destroyed the lung. This is rare case requiring pneumonectomy for Swyer-James syndrome, but we could achieve a good outcome by pneumonectomy. We have to consider the surgical indication cautiously.

(C) The Japanese Association for Chest Surgery (JACS) 